\title{
APPLICATION OF PHASE CHANGE MATERIALS (PCM'S) TO PRESERVE THE FRESHNESS OF SEAFOOD PRODUCTS
}

\author{
(APLIKASI PHASE CHANGE MATERIALS (PCM'S) \\ UNTUK MEMPERTAHANKAN KESEGARAN PRODUK MAKANAN LAUT)
}

\author{
Wiwik Pudjiastuti, Arie Listyarini, and Arief Riyanto \\ Center for Chemical and Packaging Ministry of Industry \\ JI. Balai Kimia No.1, Pekayon, Pasar Rebo, Jakarta Timur, Indonesia \\ E-mail :wiwikpudjiastuti@yahoo.com
}

Received : 27 Januari 2015; revised : 27 Maret 2015; accepted : 30 Maret 2015

\begin{abstract}
The application of Phase Change Materials (PCMs) as one of latent heat energy storage materials in smart cold system has been investigated for preserving a freshness of seafood products. In this investigation, PCMs was installed on Expanded Polystyrene (EPS) box system as insulated container. The freshness of the seafood product was shown by the time of keeping temperature during storage or distribution. Keeping temperature time of smart cold system using PCMs was compared to conventional cold system using ice cubes. The result shows that EPS box system using PCMs can prolonged the keeping temperature time and reached colder temperature than the conventional one. Microbiology test of products was monitored to prove that products occured no changes in quality.
\end{abstract}

Keywords : Phase Change Materials (PCMs), EPS box

\begin{abstract}
ABSTRAK
Aplikasi Phase Change Materials (PCMs) sebagai salah satu material penyimpan energi laten pada sistem pendingin digunakan untuk mempertahankan kesegaran produk. Pada penelitian ini, PCMs diterapkan pada sistem kotak expanded polistirena (EPS) sebagai kontainer berinsulasi. Kesegaran produk ditunjukkan oleh tercapainya waktu suhu simpan selama penyimpanan atau distribusi. Waktu suhu penyimpanan dari sistem pendingin yang menggunakan PCMs lebih rendah dibandingkan dengan pendinginan konvensional yang menggunakan es balok. Hasil ini menunjukkan bahwa sistem kotak EPS yang menggunakan PCMs dapat memperpanjang waktu suhu simpan dan mencapai suhu yang lebih rendah dibandingkan sistem pendingin konvensional. Uji mikrobiologi dilakukan untuk membuktikan tidak terjadinya perubahan pada kualitas produk.
\end{abstract}

Kata kunci : Phase Change Materials (PCMs), Kotak EPS

\section{INTRODUCTION}

Indonesia is a tropical country with ambient temperature ranging from $20{ }^{\circ} \mathrm{C}$ to $38{ }^{\circ} \mathrm{C}$ all the year. Whereas, kinds of perishable food produced are fisheries, dairy products etc. These kind of products are needed to be preserved in low temperature which can ruined by high temperature. Indonesia is one of the largest producer of fisheries products because it has a very extensive marine areas, one of the potential of marine fisheries is blue fin trevally and shrimp. In the period 2008 until 2012 the development of fish production in Indonesian reachs 5,502,622 tons in 2008 and $5,435,632$ tons in 2012 (anonymous 2015).
Perishable products have a shelf life of relatively limited. As long their shelf life, value of the perishable products continuously declined that causes a loss. Loss of the quality and quantity of seafood products starting from production to retail reach to $20 \%$ in developing countries and $10 \%$ in developed countries (Aung et al. 2014). Besides efficient and effective, the process of transportation and distribution chain of perishable products should be able to supply maintain shelf life, as well as the quality of the product.

Management temperature contribute significant maintain for shelf life, quality, and the 
safety of perishable products (Margeirsson 2009; Margeirsson 2011). In the perishable products, temperature stability is able to minimize the risk of decay due to the slowness the growth of the microorganisms. In addition to the economical, the stability of the temperature also has a safety for perishable products. Frozen food or cold system transportation and storage in an exellent method to preserve the taste, texture, nutritional value, and safety of food. Therefore, storage and transportation of food at low temperatures play an important role in the cold chain (Oro et al. 2012). Generally, frozen food must be kept below $-18{ }^{\circ} \mathrm{C}$ and the temperature should be maintained below the commercial system using ice cubes. It is well known that temperature fluctuations during the storage in ice cubes could cause negative dramatic effect to the quality of the frozen food.

PCMs (Phase Change Materials) is a material with a high melting heat, melt and freeze at a certain temperature and has the ability to remove or produce a high enough energy. PCMs fairly broad application, especially for the cooling process. PCMs has a melting point range from $-33{ }^{\circ} \mathrm{C}$ to $101{ }^{\circ} \mathrm{C}$ with various applications such as TEA-16, ethylene glycol, $\mathrm{n}$-Dodecane, and water that can be applied to protect the freshness of frozen / chilled products with melting points ranging from $-16{ }^{\circ} \mathrm{C}$, $-11.5^{\circ} \mathrm{C},-9.6{ }^{\circ} \mathrm{C}$, and $0{ }^{\circ} \mathrm{C}$ (Zalba et al. 2001; Sharma et al. 2009; Meng 2008; Agyenim et al 2010). It is widely known that PCMs can absorb large amount of heat during melting at almost constant temperature (Oro 2012; Manish et al 2013; Zsembinszki et al 2013). Insulated containers equipped with PCMs could enhance the quality of the transportation of sensitive temperature products, allowing flexibility to the cold chain management. Oro et al (2012) placed PCMs panels in freezer to improve thermal performance of freezers and studied thermal analysis of a low temperature storage unit using PCMs without refrigeration system.

Storage and transport of sensitive temperature products at the final steps of the cold chain could be enhances in order to improve the quality of food at this last stage in refrigerated or non refrigerated systems. In order to study the benefits of insulated containers equipped with PCMs, seafood products such as blue fin trevally fish and frozen shrimp was storaged in its and compare with conventional cold system that using ice cubes. The temperatures change of seafood products and PCMs was observed and recorded during storage or distribution. Microbiology test of products was monitored to prove that products occured no changes in quality.

\section{MATERIAL AND METHOD}

\section{Material}

Blue fin trevally fish, frozen shrimp, phase change materials (PCMs) $-4{ }^{\circ} \mathrm{C}$ and $-12{ }^{\circ} \mathrm{C}$ was supplied by KITECH, Expanded Polystyrene (EPS) Box with density of $18.892 \mathrm{~g} / \mathrm{cm}^{3}$, ice cube, thermocouples, data acquistion unit, and PC for data analysis.

\section{Method}

Blue fin trevally fish or shrimp was enter into boxes of $30 \mathrm{~kg}$ each. PCMs $-4{ }^{\circ} \mathrm{C}$ was mounted to each of the 3 (three) pieces of PCMs to box 1 and box 2, and 12 (twelve) $\mathrm{kg}$ of ice cubes in box 3 with configuration as shown in Figure 1 and Figure 2 for fish but for shrimp using PCMs $-26{ }^{\circ} \mathrm{C}$.

Then thermocouple inserted on fish inside each box, thermocouple at once use for direct observation temperature of fish. Trials discontinued if the temperature already reaches $0{ }^{\circ} \mathrm{C}$ because at that temperature occure the quality decrease of fish. The EPS box during trial can be shown in Figure 3.

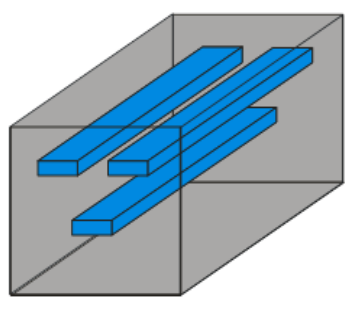

(a) Box 1

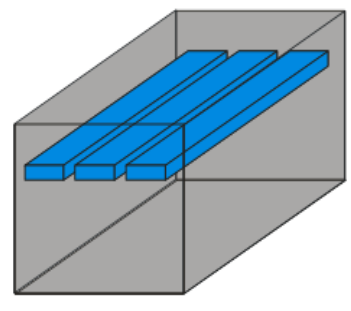

(b) Box 2

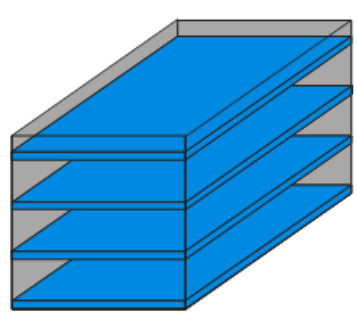

(c) Box 3

Figure 1. (a) PCMs configuration in box 1; (b) PCMs configuration in box 2; (c) ice cubes in box 3 


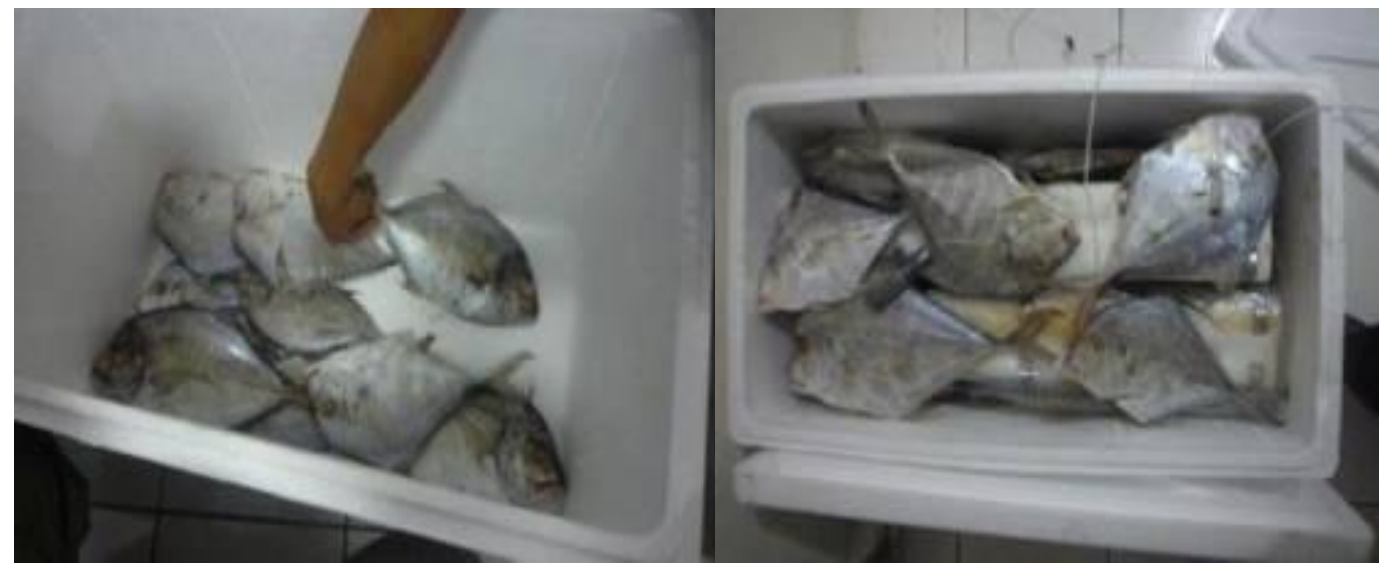

Figure 2. Blue fin trevally fish in EPS boxes

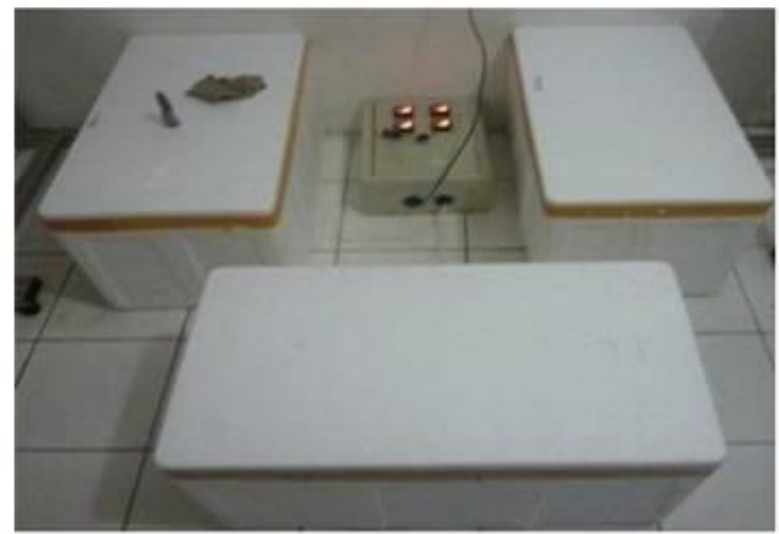

Figure 3. EPS boxes during trials

\section{RESULT AND DISCUSSION}

This research was used blue fin trevally fish and shrimp because this product is one of marine products comodity for export and requires certain conditions during storage and distribution to maintain its quality.

Based on observations in Figure 4 shown that the box 1 , box 2 , and box 3 can storage and keep fish at temperatures below $0{ }^{\circ} \mathrm{C}$ for more than 25 hours. However, there was the difference between three boxes. In the box 1 , the temperature of pile of fish reaches $-4{ }^{\circ} \mathrm{C}$, while box 2 only reaches $-2{ }^{\circ} \mathrm{C}$. The configuration of PCMs in box 1 is better than box 2 . In box 1 , heat absorption of fish and space in the box by PCMs were equitable distributed. Heat air that has been absorbed by the PCM will move naturally (natural convection) downward. Because fish was arranged compactly, the movement of cold air was obstructed by piles of fish. In the box 1 , one of the PCMs module is placed in the middle of the box. Therefore, the temperature at the center of the pile of fish in box 1 can achieve lower temperature than the box 2. Comparing the box 1 which is using PCMs with the box 3 using the ice cubes as its cooler, the results shown that box using PCMs can maintain the temperature colder than box using ice cubes. Box 1 using PCMs can maintain temperature at $-4{ }^{\circ} \mathrm{C}$ to $-5{ }^{\circ} \mathrm{C}$ for 25 hours while box 3 that using ice cubes only maintain temperature at $-3^{\circ} \mathrm{C}$ for 25 hours. This conclude that PCMs can substitute ice cubes to keep the freshness of the seafood and better than ice cubes.

To examine any changes on the quality of the stored fish using PCMs or ice cubes tested on microbial contamination has been done. Microbial contamination test results can be seen in the Table 1.

Microbiology test results in Table 1 shows that after storage in insulated containers equipped with PCMs occured no changes in quality.

Before being used the PCMs is freeze at the temperature of $-30{ }^{\circ} \mathrm{C}$ for 15 hours. Frozen shrimp either during transportation and long term storage should be kept at a maximum temperature of $-18{ }^{\circ} \mathrm{C}$. Using EPS box with 
PCMs is expected to achieve these conditions in a long time. Box 1 using PCMs on the Figure 5 can be seen that PCMs can maintain the temperature of frozen shrimp at $-18{ }^{\circ} \mathrm{C}$ for 18 hours. In comparison, frozen shrimp stored in EPS box with ice cubes can maintain temperature at $-18{ }^{\circ} \mathrm{C}$ only for 6 hours. Box 2 using PCMs with difference configuration as box 1 shown that temperature can be reached higher than box 1 but still lower than box 3 using ice cubes. So the EPS box with PCM can be used as a transport container shrimp with a considerable distance. The freshness of the shrimp still maintains, it can be seen from the appearance or visual before and after storage. Shrimp still looks fresh and there are no signs of decay. The results showed that no significant increase on microbial contamination, it can be seen in Table 2.

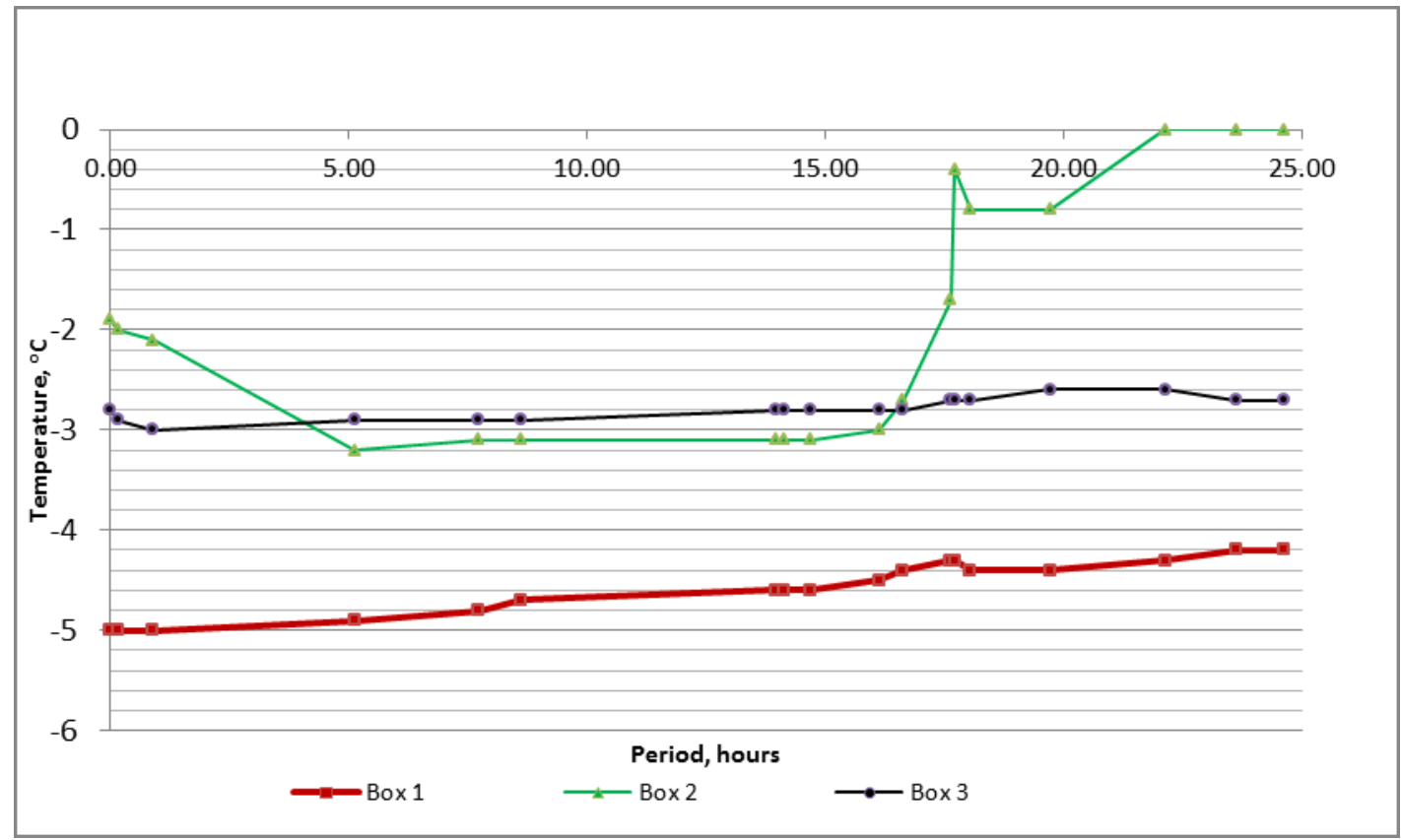

Figure 4. Temperature changes in the PCM and ice cube trials for distribution of blue fin trevally fish (from thermocouple reading)

Table 1. Microbiology testing result of blue fin trevally fish

\begin{tabular}{|c|c|c|c|c|c|c|c|}
\hline \multirow{3}{*}{ No } & Micro & & \multirow{3}{*}{ Unit } & \multicolumn{3}{|c|}{ Test result } & \multirow{3}{*}{$\begin{array}{c}\text { Requirement } \\
\text { SNI 01.2729.1- } \\
2006\end{array}$} \\
\hline & contamina & & & \multirow{2}{*}{$\begin{array}{l}\text { Early/Before } \\
\text { storage }\end{array}$} & \multicolumn{2}{|c|}{ After storage } & \\
\hline & & & & & with PCM & With ice cube & \\
\hline 1. & $\begin{array}{l}\text { Total plate } \\
\text { (TPC) }\end{array}$ & count & $\mathrm{col} / \mathrm{g}$ & $7,7 \times 10^{3}$ & $3,1 \times 10^{3}$ & $3,7 \times 10^{3}$ & Max. $5,0 \times 10^{5}$ \\
\hline 2. & E-coli & & APM/g & $<3$ & $<3$ & $<3$ & $<2$ \\
\hline 3. & Salmonella & & - & Negative & Negative & Negative & Negative \\
\hline
\end{tabular}




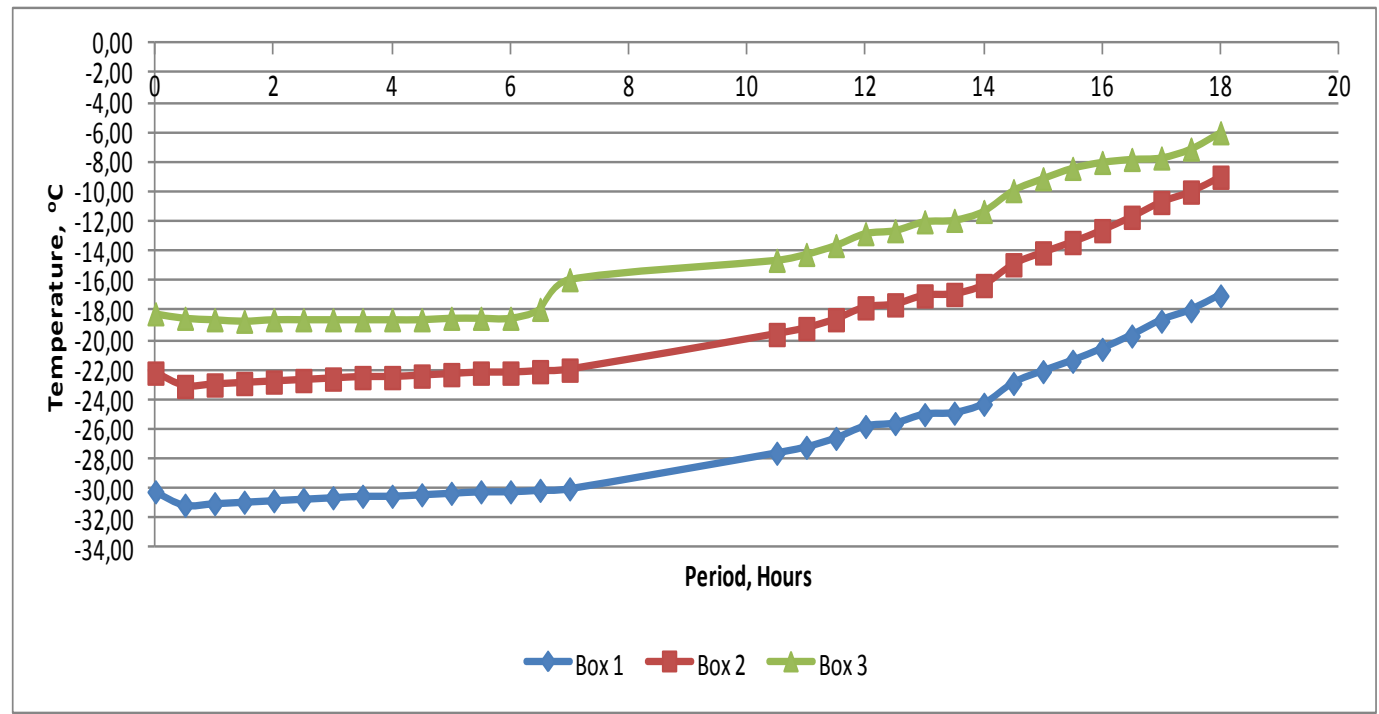

Figure 5. Temperature changes in the PCM and ice cube trials for distribution of shrimp

Table 2. Test result of microbial contamination of frozen shrimp

\begin{tabular}{|c|c|c|c|c|c|}
\hline \multirow[b]{2}{*}{ No } & \multirow{2}{*}{$\begin{array}{l}\text { Microbial contamination } \\
\text { parameter }\end{array}$} & \multirow[b]{2}{*}{ Unit } & \multicolumn{2}{|c|}{ Test result } & \multirow{2}{*}{$\begin{array}{c}\text { Requirements } \\
\text { SNI 01-2705.1- } \\
2006\end{array}$} \\
\hline & & & $\begin{array}{l}\text { Early/Before } \\
\text { storage }\end{array}$ & After storage & \\
\hline 1. & Total Plate Count (TPC) & $\mathrm{col} / \mathrm{g}$ & $8,8 \times 10^{4}$ & $4,5 \times 10^{5}$ & $\operatorname{Max} .5,0 \times 10^{5}$ \\
\hline 2. & E Coli & APM/g & $<3$ & $<3$ & $<2$ \\
\hline 3. & salmonella & - & Negative & Negative & Negative \\
\hline
\end{tabular}

\section{CONCLUSION}

EPS box using PCMs as cold system for storage or distribution of fish and shrimp can keep in its temperature up to approximately more than 25 hours for fish and 15 hours for shrimp. PCMs better than ice cubes for maintaining temperature during storage or distribution of fresh fish, frozen shrimp, and other seafood products. PCMs can also reuse until many times as long as module of PCMs are not damage while ice cubes only for once.

\section{REFERENCES}

Agyenim, F., N. Hewitt, P. Eames, and M. Smyth. 2010. A review of materials, heat transfer and phase change problem formulation for latent heat thermal energy storage systems (LHTESS). Renewable and Sustainable Energy Reviews. Vol. 14. (2): $615-628$.

Aung, M.M. and Y.S. Chang. 2014. Temperature management for the quality assurance of a perishable food supply chain. Food Control 40:198 - 207.

Mai, N., B. Margeirsson, S. Maregeirsson, S. Bogason, and S. Arason. 2012. Temperature mapping of fresh fish supply chains-air and sea transport. Journal of food process engineering 35 (4): $622-656$.

Margeirsson, B., R. Gospavic, H. Palsson, S. Arason, and V. Popov. 2011. Experimental and numerical modelling comparison of thermal performance of expanded polystyrene and corrugated plastic packaging for fresh fish. International journal of refrigeration 34(2):573 - 585.

Meng, Q. and J.Hu. 2008. A poly(ethylene glycol)-based smart phase change materials. Solar Energy Materials \& Solar Cells 92: 1260 - 1268

Oro, E., L. Miro, M.M. Farid, and L.F. Cabeza. 2012. Improving thermal performance of freezers using phase change materials. International journal of refrigeration 35:984 - 991.

Oro, E., L. Miro, M.M. Farid, and L.F. Cabeza. 
2012. Thermal analysis of a low temperature storage unit using phase change materials without refrigeration system. International journal of refrigeration 35: $1709-1714$.

Rathod, M.K. and J.Banerjee. 2013. Thermal stability of phase change materials used in latent heat energy storage systems: A review. Renewable and sustainable energy reviews 18: 246 258.

Schossig, P. 2007. Phase Change Materials For Thermal Energy Storage Applications. .Institute Solare Enery Systeme, Freiburg, Jerman

Sharma, A., V.V. Tyagi, C. R Chen, and D. Buddhi. 2009. Review on thermal energy storage with phase change materials and applications. Renewable and sustainable energy reviews 13 (2) : 318-345.
Zalba, B., J.M. Marin, L.F. Cabeza, H. Mehling. 2003. Review on thermal energy storage with phase change : materials, heat transfer analysis and application. Applied thermal engineering 23: 251 283.

Zsembinszki, G., C. Sole, A. Castell, G. Perez, and L.F. Cabeza. 2013. The use of phase change materials in fish farms: A general analysis. Applied energy 109: 488 - 496.

Anonymous.2015. Volume produksi perikanan tangkap di laut menurut jenis ikan dan provinsi.http://statistik.kkp.go.id/index.p

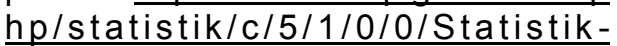
$\mathrm{P}$ erikan a n T a n g k a PerairanLaut/?perairan id=\&subentitas $\mathrm{id}=18 \sim 1 \&$ view data $=1$ \&tahun start $=20$ 05\&tahun to $=2012$ \&tahun $=2015 \&$ filter =Lihat+Data+\%C2\%BB. (Accessed M a r c h $20, \quad 2015$ ). 